\title{
Masa Orientasi Siswa/Mahasiswa Sebagai Media Orientasi Pendidikan Tanpa Kekerasan
}

\author{
Hujair AH. Sanaky*
}

\begin{abstract}
Any kind of violence is not acceptable in any sort of values and rights, moreover if it occured in education circumstances. It is indeed against universal values and norms. Education is a medium and tool to internalize norms, good attitude and positive values into students personality. But it sometimes becomes dilematics when teachers find difficulties in doing the job, or when they deal with difficult students, should they use hard lead-to-violence way or soft way? This article found that no reason to use hard-violence way to deal with such problem. Teachers should use soft way to teach students to be pro-social with the spirit of nonviolence education. Doing so, education institutions (schools or higher educations) must provide standard operational procedure for teachers and provide a tools by which teachers can use to control any students activities that potentially leads to violence, verbally or phisically. In this way, law enforcement also takes an important part.
\end{abstract}

Keywords: non-violence education, humanism, law enforcement.

\section{A. Pendahuluan}

Setiap tahun ajaran baru, untuk menyambut kedatangan siswa atau mahasiswa baru, selalu diadakan berbagai kegiatan pengenalan kampus yang dikenal dengan istilah Masa Orientasi Siswa (MOS) untuk tingkat sekolah menengah atau Orientasi Pengenalan kampus (OSPEK) untuk tingkat perguruan tinggi. Para siswa di sekolah disibukkan dengan berbagai permintaan yang anehaneh dari panitia MOS. Mau tidak mau para orangtua pun ikut sibuk. Demikian juga para mahasiswa baru yang diminta oleh "senior" untuk selalu mencari sesuatu yang unik atau tak wajar dalam waktu yang sangat singkat. Orangtua siswa dan mahasiswa baru selalu disibukkan dan dihadapkan pada tradisi klasik pengenalan kampus yang sebenarnya tidak memiliki dampak terhadap kepribadian dan pengembangan intelektualitas siswa dan mahasiswa baru ketika mengikuti pelajaran dan perkuliahan.

MOS dan OSPEK didesain sedemikian rupa sebagai ajang pengenalan sekolah dan kampus dengan berbagai kegiatan, seperti kegiatan barisberbaris, berlari-lari, bernyanyi-nyanyi, ceramahceramah, diskusi-diskusi, bakti sosial dan sebagainya. Kegiatan-kegiatan tersebut dianggap sebagai ajang pembentukan kepribadian siswa dan mahasiswa yang akan masuk sekolah atau kuliah. Tapi sayangnya, sering terjadi kekerasan, baik kekerasan dalam bentuk verbal (tidak langsung) maupun kekerasan fisik (langsung) yang memiliki dampak yang sangat buruk bagi siswa/ mahasiswa dan bagi lembaga pendidikan di Indonesia secara umum.

Pada awal tahun ajaran, siswa, mahasiswa baru dan orangtua selalu disibukkan untuk mencari sesuatu yang ditentukan oleh panitia atau senior yang kadang-kadang tidak wajar. Misalnya, memegang ular, mencari jenis ikan yang beratnya ditentukan, membawa dot, memberi nama julukan pada dirisendiri, menirukan suara binatang tertentu, berbicara dengan tembok, membuat topi dari bola, membuat topi dari koran, membuat tas dari kardus, mencarikan suatu jenis makanan yang tidak ada merknya dan lain sebagainya. Bila siswa atau mahasiswa tidak memenuhi permintaan tersebut, mereka akan diberi hukuman, dan hukuman tersebut selalu tidak mendidik. Bentakan-bentakan yang begitu keras dan suara pukulan di dinding oleh panitia adalah perilaku yang biasa terjadi dalam kegiatan-kegiatan tersebut.

Dalam situasi seperti itu, terlihat siswa atau mahasiswa baru tidak berdaya dan dibuat tidak 
kritis karena tidak memiliki hak untuk membantah. Tentu saja hal ini mengabaikan hak-hak dan kebutuhan mendasar dalam dunia intelektual yang meniscayakan sikap kritis. Alasan klasik dan tidak dapat dipertanggungjawabkan adalah penggembelengan mental dan perilaku. Apakah benar seperti itu pola dan strategi penggembelengan mental? Secara jujur dapat dikatakan bahwa kegiatan tersebut (memegang ular, beratribut yang aneh-aneh, dan sebagainya) bila diteropong dengan menggunakan kacamata pedagogik tidak memiliki nilai-nilai edukatif dan tidak mendidik. Sebaliknya pola tersebut hanya mengandung nilai-nilai yang justru membahayakan karena mengaburkan nilainilai pembinaan dan pendidikan.

\section{B. Penggemblengan atau Perilaku Feodalisme?}

Dunia pendidikan Indonesia antara apa yang diidealkan (das solen) dengan realitas (das sein) sering berbeda. Nilai-nilai ideal telah disosialisasikan dan ditransferkan pada peserta didik melalui proses belajar-mengajar, namun seiring dengan itu kekerasan masih saja sering terjadi. Memang tidak seorang pun menginginkan terjadinya tindak kekerasan, terlebih di lembaga pendidikan yang sepatutnya menyelesaikan masalah secara edukatif. Tetapi mengapa masih dijumpai perilaku kekerasan? Apakah ada sesuatu yang salah atau memang demikian rapuhkah dunia pendidikan di Indonesia, sehingga kekerasan sering terjadi, dan cenderung selalu meningkat? Bisa disebutkan di sini adalah kekerasan guru terhadap murid, tawuran pelajar, tawuran mahasiswa, kekerasan dalam kegiatan siswa dan mahasiswa, seperti kekerasan dalam MOS dan OSPEK (Assegaf, 2009).

Kekerasan yang terjadi dalam kegiatan MOS dan OSPEK seakan-akan sudah membudaya di lembaga-lembaga pendidikan di Indonesia karena selalu terjadi pada setiap tahun ajaran baru. Kita selalu membaca dan mendengar berita tentang aksi kekerasan, baik yang bersifat verbal maupun fisik, bahkan sampai merenggut nyawa. Namun kenapa praktik kekerasan ini terus-menerus terjadi di dunia pendidikan kita? Apa penyebabnya? Apakah ada sesuatu yang salah dari sistem pendidikan kita?

Melihat fenomena MOS dan OSPEK seperti yang dijelaskan di atas, tampak ada feodalisme terstruktur dalam relasi antar generasi di dunia pendidikan kita. Perilaku ini masih tumbuh subur sejak dari kegiatan yang disebut MOS dan OSPEK, atau sejenisnya, dan berlanjut selama siswa atau mahasiswa menjalani kegiatan belajar di sekolah atau kampus. Lihat saja pola hubungan antar angkatan siswa/ mahasiswa atau antara siswa dengan guru dan mahasiswa dengan dosen.

Institusi pendidikan pada dasarnya berfungsi sebagai tempat untuk membentuk manusia-manusia berjiwa humanis yang sederajat (equal). Apapun alasannya apakah kegiatan tersebut untuk ajang perkenalan ataukah membangun mental-kepribadian untuk siap masuk sekolah atau kuliah, kegiatan tersebut telah membangun sikap feodal sejak awal ketika siswa/ mahasiswa berkenalan dengan sekolah atau perguruan tinggi.

Salah satu kelemahan mendasar dalam masalah ini adalah penegakan hukum dalam kegiatan tersebut masih sangat rendah. Inilah kemudian yang melanggengkan seluruh struktur dan praktek feodalisme yang terjadi dalam kegiatan ekstrakurikuler di lembaga-lembaga pendidikan. Tidak jarang praktik ini kemudian melahirkan kekerasan yang laten. Katakan saja, kontrol dan pengawasan dari institusi pendidikan sangat lemah, bahkan mungkin saja tidak ada. Sehingga lembaga pendidikan secara institusional maupun individu, dalam hal ini para pimpinannya, tidak mengetahui praktek feodalisme, kekerasan dan bahkan perilaku premanisme yang terjadi di lembaga yang dipimpinnya. Dari realitas tersebut, harus ada keberanian terus menerus dari para pemegang keputusan baik di lembaga pendidikan atau pemerintah yang disuarakan, baik di forum resmi maupun tidak resmi (http://anggara.org/2007/11/26/ ancaman-kekerasan-di-lembaga-pendidikan/).

Berkembangnya kekerasan dalam dunia pendidikan juga terjadi karena sistem yang telah melembaga, sehingga menjadikultur organisasi. Tesis ini dapat dapat dibuktikan dengan melihat fenomena yang terjadi di beberapa lembaga pendidikan dengan merajalelanya irasionalitas bentuk kekerasan dalam pendidikan. Hal ini menunjukkan betapa lemahnya sistem pendidikan kita. Kelemahan sistem ini terjadi karena lemahnya kepemimpinan dalam lembaga pendidikan yang diakibatkan oleh tidak jelasnya visi pendidikan. Jika keadaan ini terus berlangsung, maka perilaku dan tindak kekerasan dalam pendidikan tidak dapat diatasi. Daftar kekecewaan juga diperpanjang dengan munculnya kasus-kasus 
kekerasan yang melibatkan oknum guru dan murid. Bahkan di lingkungan kampus ada kekerasan secara turun-temurun yang disebut dengan kegiatan perpeloncoan yang dilakukan oleh mahasiswa senior pada mahasiswa yuniornya secara tersistematik dan tersktruktur melalui kegiatan-kegiatan resmi.

Agar perilaku kekerasan dalam dunia pendidikan dapat diredam, harus ada visi pendidikan yang jelas dan sistem pendidikan yang terbuka atas kontrol publik. Masyarakat harus mempunyai hak untuk mengetahui bagaimana sistem pendidikan dan pembinaan dalam lembaga pendidikan. Orangtua murid dan mahasiswa harus tahu apa manfaat kegiatan MOS dan OSPEK tersebut terhadap kompetensi yang akan dimiliki oleh peserta didik. Di sini diperlukan keterbukaan lembaga-lembaga pendidikan terhadap keingintahuan masyarakat. Maka, untuk menciptakan lembaga pendidikan yang terbuka atas kontrol publik, dibutuhkan tiga syarat; pertama, adanya figur pemimpin yang mempunyai karakter dan visi pendidikan yang jelas agar dapat menciptakan struktur dan kultur pendidikan yang sehat; kedua, adanya figur pemimpin yang memiliki kemampuan manajemen memadai untuk mengatur dan mengontrol berbagai kegiatan siswa di sekolah/ kampus; ketiga, adanya program yang memungkinkan setiap lembaga pendidikan untuk mempertanggungjawabkan kinerjanya kepada pemangku kepentingan, yaitu orangtua dan masyarakat; dan keempat, secara terbuka dapat menerima kritik dan saran yang positif demi perbaikan dari semua pihak (http://www.bloggaul. com/foksraad/readblog/74581/kekerasan-dalamdunia-pendidikan).

Institusi pendidikan merupakan sebuah ranah (domain) sosial yang diharapkan mampu berperan sebagai kawah candradimuka untuk lahirnya generasi yang memiliki intelektualitas dan moralitas serta menjunjung tinggi nilai-nilai kemanusian, demokrasi, kebebasan dan perdamaian. Bila demikian, maka perilaku feodalisme, kekerasan dan perpeloncoan tidak harus terjadi dalam berbagai kegiatan di lembaga-lembaga pendidikan. Lembaga pendidikan diharapkan mampu mambangun dan membentuk karaktek dan kepribadian bangsa (nation and character building), membangun moral keagamaan, demokrasi, kebebasan, dan nilai-nilai kemanusiaan yang tinggi. Pembentukan karakter dan kepribadian bangsa merupakan hal yang sangat penting bahkan sangat mendesak, agar masyarakat memiliki keadaban (civility), yang merupakan suatu ciri dari masyarakat madani yang beradab. Upaya ke arah ini harus dilakukan melalui kegiatan dan aktivitas pembinaan yang menyenangkan, memanusiakan dan memberdayakan potensi siswa/ mahasiswa. Lembaga atau institusi pendidikan diekspresikan sebagai center of excellence bagi terwujudnya pemberdayaan potensi manusia. Hal ini menunjukkan bahwa sebuah institusi pendidikan berarti sebuah lingkungan yang jauh lebih berwibawa dibandingkan dengan lingkungan pabrik, bengkel, pasar, hotel, atau dibandingkan barak militer. Karena secara eksistensial, setiap manusia dalam lingkungan pendidikan didorong untuk mengenal hakikat kemanusiaan dirinya secara utuh, potensi dirinya dengan berbagai macam potensi yang dimiliki. Di samping itu, dalam dunia pendidikan, seseorang diajarkan untuk belajar menerima keberadaan orang lain dengan prinsip teposelira. Itulah mengapa pembudayaan akal budi dalam dunia pendidikan seiring sejalan dengan pengukuhan hati nurani. Karena sesungguhnya intelektualitas berfungsi untuk merawat hati nurani dan merawat perilaku (Anwari, 2009).

Karakter bangsa kita sesungguhnya adalah bangsa yang berbudaya tinggi, berbudi halus, toleran, tepaselira dan menjungjung tinggi nilainilai kemanusiaan. Pertanyaannya, kenapa mutiaramutiara instrumen tersebut seakan-akan hilang teggelam ditelan masa dari kehidupan bangsa ini? Bila kita menyaksikan berbagai tayangan di televisi dan berbagai berita di media cetak mengenai bentukbentuk tindak kekerasan yang dilakukan di lembaga pendidikan dan masyarakat, maka pertanyaan tersebut layak untuk diajukan (Kedaulatan Rakyat, 26/02/2009).

Pemerintah telah merespon persoalan di atas dengan pelbagai peraturan perundangan yang lebih responsif, seperti UU Perlindungan Anak (UU PA). Kenyataannya, UU ini tidak mampu menghapus tindak kekerasan tersebut. Kekerasan demi kekerasan terus berlanjut dan intensitasnya makin meningkat. Artinya, di era modern, era reformasi dan globalisasi ini, banyak sekali kejadian-kejadian yang sangat ironis, menyedihkan dan memalukan menimpa bangsa kita terutama dalam dunia pendidikan. Tentu saja hal itu sangat tidak sesuai dengan tujuan, visi dan misi pendidikan nasional bangsa ini yang berfungsi untuk mengembangkan kemampuan dan membentuk watak serta peradaban bangsa yang 
bermartabat, beriman dan bertakwa kepada Tuhan Yang Maha Esa, berakhlak mulia, kreatif, mandiri, dan menjadi warga negara yang demokratis serta bertanggung jawab. Tujuan pendidikan nasional tersebut sangat mulia, tapi pendidikan dengan bentuk kekerasan yang ada di bangsa kita ini selalu saja ada dan tampaknya belum dapat terselesaikan dengan baik (http://beutyreligi.wordpress.com/2007/06/07/ pendidikan-tanpa-kekerasan/).

Berbagai tindak kekerasan yang terjadi di institusi pendidikan kita jelas memprihatinkan. Para pelajar (siswa dan mahasiswa) merupakan generasi penerus dan calon pemimpin bangsa ini. Bila awal masuk sekolah atau kampus mereka sudah dikenalkan dengan perilaku kekerasan, baik aktif (terlibat langsung), pasif (menyaksikan) maupun sebagai korban (victims), maka cara-cara kekerasan pulalah yang akan mereka tempuh untuk menyelesaikan segala masalah ketika mereka sudah terjun ke masyarakat.

Berbeda pendapat tentu saja boleh, berunjuk rasa juga boleh, bahkan yang terakhir ini merupakan salah satu ciri demokrasi. Yang tidak boleh adalah menyelesaikan perbedaan pendapat dan masalah dengan kekerasan. Barangkali ada baiknya bila tema-tema seperti demokrasi, menghargai pendapat orang lain, dan penyelesaian perbedaan pendapat melalui dialog dan jalan damai dijadikan kurikulum di sekolah-sekolah dan kampus-kampus. Orangtua, pimpinan lembaga pendidikan, dosen, guru-guru dan para pemimpin bangsa juga harus menjadi teladan yang utama dan pertama.

Hal lain yang penting adalah perlunya diberlakukan kontrol sosial dengan cara memberi sanksi kepada siswa yang melanggar aturan. Namun seringkali cara yang biasa digunakan adalah dengan menghukum siswa, mulai dari yang ringan berupa ungkapan verbal yang menyakitkan hingga hukuman fisik. Tidak jarang siswa mendapatkan hukuman fisik yang tidak sepadan dengan kesalahan siswa. Cara ini tentu saja tidak efektif dan justru ikut melanggengkan tradisi kekerasan. Agar hukuman tersebut efektif, hukuman yang diberikan harus bisa mendatangkan pencerahan dan bimbingan terhadap siswa. Bentuk hukuman yang diberikan harus humanis. Pendekatan dan strategi yang dilakukan tersebut memang berbeda dengan konsep pendidikan konvensional tentang reward dan punishment yang berfungsi sebagai sebagai reinforcerment (penguatan).

\section{Indikator Terjadinya Kekerasan}

Ada beberapa indikator model kekerasan yang dapat diamati sebagai proses terjadinya kekerasan, yaitu:

(1) Kekerasan terbuka. Kekerasan yang dilakukan seseorang terhadap orang lain yang dapat dilihat dan diamati secara langsung. Seperti perkelahian, tawuran, bentrokan massa, dan semua hal yang berkaitan dengan tindakan fisik lainnya;

(2) Kekerasan tertutup. Kekerasan yang dilakukan seseorang terhadap orang lain secara tersembunyi, seperti ancaman dan intimidasi;

(3) Kekerasan agresif. Kekerasan yang dilakukan seseorang terhadap orang lain dengan tujuan mendapatkan sesuatu, seperti perampokan, pemerkosaan, dll.

Ketiga indikator model kekerasan di atas adalah kekerasan yang kerap terjadi dalam dunia pendidikan kita saat ini. Tindakan kekerasan tidak pernah diinginkan oleh siapapun, apalagi di lembaga pendidikan yang sepatutnya menyelesaikan masalah secara edukatif. Namun tak dapat dihindari, di lembaga pendidikan ternyata masih sering terjadi tindakan yang sifatnya destruktif. Beberapa analisa yang dapat diajukan untuk mencermati pemicu terjadinya kekerasan dalam dunia pendidikan, adalah:

(a) Kekerasan dalam dunia pendidikan muncul akibat adanya pelanggaran yang disertai dengan hukuman terutama berupa hukuman fisik;

(b) Kekerasan dalam dunia pendidikan dapat terjadi akibat buruknya sistem dan kebijakan dunia pendidikan yang berlaku. Kurikulum dunia pendidikan di negeri ini ternyata lebih mengandalkan aspek kemampuan kognitif dan mengabaikan aspek pendidikan afektif sehingga proses humanisasi dalam pendidikan menjadi sesuatu yang jauh dari harapan. Kurikulum kita mengabaikan pendidikan budi pekerti yang mendidik kehalusan, sopan santun, menghargai yang lebih tua, menyayangi yang lebih muda dan menghormati hak-hak asasi (Assegaf, 2009);

(c) Model dan sistem pendidikan kita bisa jadi akan menghasilkan manusia-manusia Indonesia yang tertekan, tidak kritis, bertindak dan berpikir 
dalam acuan struktur kekuasaan yang hanya mengandalkan kepentingan sekelompok kecil masyarakat (Tilaar, 1999: 4);

(d) Kekerasan dalam pendidikan dipengaruhi oleh lingkungan masyarakat dan tayangan media massa yang sarat dengan aksi-aksi kekerasan dan ditayangkan secara berlebihan.

(e) Kekerasan dalam pendidikan merupakan cerminan dari perkembangan kehidupan masyarakat yang mengalami transformasi begitu cepat sehingga membuka ruang bagi timbulnya sikap instant solution;

(f) Kekerasan dalam pendidikan dipengaruhi oleh latar belakang sosial-ekonomi pelaku (Assegaf, 2009).

\section{Bagaimana Pendidikan Meredam Kekerasan}

Pendidikan adalah proses menaburkan benihbenih budaya dan peradaban manusia yang hidup dan dihidupi oleh nilai-nilai atau visi yang berkembang dan dikembangkan dalam sebuah masyarakat. Itulah mengapa pendidikan juga berfungsi sebagai salah satu bentuk proses pembudayaan (Tilaar, 1999:9). Pendidikan dalam perspektif UU 20 Tahun 2003 didefinisikan sebagai usaha sadar dan terencana untuk mewujudkan suasana belajar dan proses pembelajaran agar peserta didik secara aktif mengembangkan potensi dirinya untuk memiliki kekuatan spiritual, pengendalian diri, kepribadian, kecerdasan, akhlak mulia, serta keterampilan yang diperlukan bagi dirinya, masyarakat, bangsa dan negara. Dalam perspektif yang sama, pendidikan berfungsi untuk mengembangkan kemampuan dan membentuk watak serta peradaban bangsa yang bermartabat dalam rangka mencerdaskan kehidupan bangsa.

Begitu mulia tujuan pendidikan nasional sebagaimana yang tersurat dalam UU tersebut. Namun pertanyaannya, kenapa praktek kekerasan terus-menerus terjadi di masyarakat dan di dunia pendidikan kita? Apakah ada sesuatu yang salah dari sistem pendidikan dan kehidupan kita di Indonesia? Bila dicermati, ada beberapa penyebab mendasar, yaitu:

(1) Dari pengajar itu sendiri. Masih cukup banyak para pengajar, bahkan di sekolah-sekolah negeri yang cukup ternama, melakukan praktik kekerasasn seperti menampar, menjewer atau mencubit. Tindakan kekerasan yang paling sering dilakukan adalah intimidasi secara psikologis kepada para peserta didik;

(2) Terjadi perilaku feodalisme. Perilaku ini masih tumbuh subur di hampir seluruh lembaga pendidikan. Perilaku ini dimulai dari kegiatan yang namanya MOS, OSPEK dan atau sejenisnya. Tendensinya adalah mengekalkan praktek feodalisme di lembaga pendidikan yang berbuntut pada perilaku kekerasan. Kegiatan tersebut harus ditinjau kembali, karena seharusnya institusi pendidikan berfungsi membentuk manusia-manusia merdeka yang berjiwa demokratis;

(3) Penegakan hukum yang masih rendah. Inilah yang kemudian melanggengkan seluruh struktur dan praktik kekerasan yang terjadi di lembaga pendidikan. Kontrol dan pengawasan institusi pendidikan sangat lemah, sehingga lembaga pendidikan secara institusional maupun pimpinannya secara personal tidak mengetahui praktik kekerasan dan premanisme yang terjadi di lembaga yang dipimpinnya;

(4) Orangtua perlu melakukan kontrol dan pengawasan terhadap putra-putrinya. Orangtua diharapkan dapat membuka komunikasi dua arah yang jujur dan terbuka untuk anak.

Harus ada keberanian melakukan tindakan untuk melawan praktik kekerasan secara terus menerus, baik di forum seminar atau diskusi informal (http:// anggara.org/2007/11/ 26/ancaman-kekerasan-dilembaga-pendidikan/). Memang harus ada upaya dan usaha untuk menghentikan kekerasan dalam dunia pendidikan, karena tidak sesuai dengan visi dan misi pendidikan. Anak harus dipandang sebagai siswa, sebagai guru, sekaligus sebagai teman. Guru sebagai tenaga profesional dituntut untuk menciptakan pembelajaran yang menyenangkan, memanusiakan, dan memberdayakan potensi anak dengan memperhatikan beragam kecerdasan anak. Strategi pembelajaran yang digunakan diupayakan mampu menciptakan suasana pembelajaran dan lingkungan belajar yang ramah sehingga anak mudah menerima informasi yang disampaikan. Disamping itu perlu reformulasi tentang reward dan punishment dalam praktik pendidikan di keluarga, sekolah dan masyarakat sesuai dengan prinsip-prinsip dalam ajaran Islam dan dilakukan secara bertahap serta 
disesuaikan dengan tingkat kesalahan yang dilakukan (Hasil Seminar Nasional, Reaktualisasi Pendidikan Tanpa Kekerasan, Prodi Pendidikan Agama Islam, Fakultas Ilmu Agama Islam, Universitas Islam Indonesia Yogyakarta, 21 Februari 2009).

Hal lain yang perlu dilakukan adalah penanaman nilai-nilai perilaku pro-sosial. Misal; mendisiplinkan peserta didik dengan cara yang positif, mengajarinya menyelesaikan masalah konflik tanpa kekerasan dengan diikuti pedoman yang jelas dan mengikat bagi guru dan peserta didik, serta pengawasan kooperatif oleh komunitas sekolah, orangtua dan tokoh masyarakat. Hal ini semestinya dilakukan untuk mengatasi tindak kekerasan seperti tawuran antar pelajar dan tindak kejahatan serta kekerasan lain yang sering terjadi di sekolah dan luar sekolah.

Darimanamemulaimeredamperilakukekerasan yang membudaya ini? Menurut penulis, proses ini harus dimulai dari tiga lingkungan pendidikan yaitu lingkungan rumah atau keluarga, lingkungan sekolah, dan lingkungan masyarakat.

Pertama, lingkungan rumah atau keluarga. Rumah dan keluarga adalah tempat anak pertama kali belajar mengenal peraturan dan norma. Orangtua mulai melakukan pembiasaan perilaku, contohcontoh perilaku yang baik, dengan pembiasaan sikap moral, akhlak, sopan santun, menciptakan sikap disiplin, sikap menghargai sesamanya, sikap menghargai pendapat walaupun berbeda, menghormati yang tua, menyangi yang muda, dan menghindari tindakan kekerasan dalam lingkungan keluarga. Sudah barang tentu dalam pembelajaran di lingkungan keluarga, anak cenderung mencontoh perilaku yang terjadi di rumah yang kemudian menjadi kebiasaan dan perilaku anak.

Namun di sisi lain, banyak orangtua yang menganggap kekerasan pada anak sebagai hal yang wajar. Kekerasan dianggap sebagai bagian dari upaya mendisiplinkan anak. Tapi mereka sendiri lupa bahwa orangtua adalah orang yang paling bertanggung jawab dalam mengupayakan kesejahteraan, perlindungan, peningkatan kelangsungan hidup dan optimalisasi tumbuh kembang anaknya. Bila dicermati, kekerasan yang terjadi dalam lingkungan keluarga menduduki porsi terbesar dalam kasus kekerasan yang menimpa anak-anak pada rentang usia 3 sampai 18 tahun. Sudah barang tentu dalam proses belajar ini, anak cenderung melakukan kesalahan. Bertolak dari kesalahan yang dilakukan, tentu saja anak akan lebih mengetahui tindakantindakan yang bermanfaat dan tidak bermanfaat, patut atau tidak patut. Pada hakekatnya, kekerasan orangtua terhadap anaknya boleh saja dilakukan, asalkan tidak melanggar norma-norma yang ada di masyarakat dengan dalih supaya anak patuh pada orangtua. Hakikat anak sebagai titipan dari sang Ilahi mestinya harus dijaga sebaik mungkin dan sudah seharusnya kita didik setinggi mungkin jangan sampai terlantarkan (http://beutyreligi.wordpress. com/2007/06/07/pendidikan-tanpa-kekerasan/).

Kedua, lingkungan sekolah. Sekolah harus berusaha membangun dan mengembangkan ranah kognitif, afeksi, dan psikomotorik anak dalam pembelajaran. Para guru harus memiliki model pembelajaran yang berpusat pada siswa (student centered) dengan mengoptimal semua potensi siswa, memanusiakan dan menyenangkan dengan memperhatikan ragam kecerdasan yang dimiliki siswa. Menurut Howard Gardner dalam bukunya Multiple Intelligences, dikutip Seto Mulyadi, menyatakan bahwa skala kecerdasan yang selama ini dipakai ternyata memiliki banyak keterbatasan sehingga kurang dapat meramalkan kinerja kesuksesan untuk masa depan seseorang.

Menurut Gardner, kecerdasan seseorang meliputi unsur-unsur: kecerdasan matematikalogika, kecerdasan bahasa, kecerdasan musikal, kecerdasan visual, kecerdasan kinestetik, kecerdasan interpersonal, kecerdasan intrapersonal dan kecerdasan naturalis (Mulyadi, 2009). Dengan mengetahui ragam kecerdasan tersebut, para guru didorong untuk dapat memahami jenis kecerdasan murid-muridnya, sekaligus dapat mengajarkan materi pelajaran dan mengembangkan serta memberdayakan murid-muridnya sesuai dengan jenis kecerdasan tersebut.

Respon sekolah terhadap fenomena kekerasan sendiri bermacam-macam. Beberapa sekolah yang sangat maju sudah menciptakan sistem yang cukup efektif untuk mengurangi insiden kekerasan dan memberi dukungan pada korban kekerasan. Tapi sampai kini ada sejumlah guru yang masih menganggap atau merasa bahwa hukuman fisik sebagai strategi dalam pembelajaran untuk menegakkan wibawa guru di mata murid. Maka, guru sengaja membuat atau mengondisikan suasana agar murid takut pada guru. Maka setelah terkondisi dalam suasana takut, si murid akan mau melaksanakan perintah gurunya. Menurut guru, 
yang penting si murid tidak berani berkutik di hadapan guru demi wibawa. Bahkan sangat ironis sekali, ada sebagian guru yang bangga jika ditakuti murid. Paradigma hukuman menjadi fenomena bagi sebagian guru yang kurang percaya diri dan kurang mampu untuk mengelola pembelajaran, sehingga menurut mereka "tanpa hukuman, murid tidak akan disiplin."

Kekerasan dalam dunia pendidikan dapat dikelompokkan menjadi dua, yaitu:

(1) Kekerasan fisik, yakni menyakiti siswa secara fisik. Contoh, menjewer, menendang, memukul, menempeleng, mencubit, sampai menjambak rambut. Konon strategi ini digunakan oleh guru zaman penjajahan sampai beberapa waktu kemudian. Kini guru membawa kayu atau alat pemukul lainnya untuk menyakiti fisik siswa bukan zamannya lagi. Mestinya hukuman menyehatkan fisik si anak atau yang bersifat mendidik - membuat siswa lebih pintar dengan hukuman, bukan malah membuat si anak harus berobat gara-gara hukuman. Keberhasilan masa lalu dengan kekerasan bukan terletak pada cara kekerasan itu, melainkan motivasi peserta didik memang tinggi dalam belajar.

(2) Kekerasan psikis. Di antara kekerasan psikis ini adalah membunuh karakter anak dengan meneror mental si anak. Misalnya, anak tidak mengerjakan perkejaan rumah langsung dihukum, anak tidak diperkenankan ikut pelajaran gara-gara terlambat, tanpa ditanyakan terlebih dahulupenyebabketerlambatanitu, anak tidak diperkenankan ikut pelajaran gara-gara belum bayar uang sekolah, padahal bayar uang sekolah bukan urusan anak. Jika belum bayar uang sekolah mestinya orangtua yang dipanggil ke sekolah untuk memberikan keterangan soal keterlambatan pembayaran. Cara-cara yang dilakukan tersebut telah menutup komunikasi dan dialog dengan siswa yang berkaitan dengan kesalahan yang dilakukan. Anak harus menerima hukuman, padahal mereka ingin menyampaikan kejadian yang sesungguhnya. Dalam kondisi ini, bahkan bukan si anak saja yang menjadi sasaran marah dan makian, tapi kadang orangtua pun disebut-sebut dan diseretseret dalam kasus siswa di sekolah. Kata-kata yang kadang dilontarkan guru misalnya: apa begitu yang diajar sama orangtuamu? Saya tidak peduli walau orangtua-mu berpangkat tinggi sekalipun, dan seterusnya. Kondisi seperti ini menunjukkan bahwa beberapa guru masih arogan, kehilangan kendali dan kehilangan akal dalam mendidik. Kondisi ini menunjukkan sikap guru yang kekurangan ide dan strategi, sehingga mereka menggunakan kekerasan dalam mendidik dan menyelesaikan masalah siswanya. Pembelajaran dengan strategi kekerasan sudah waktunya untuk ditinggalkan dan dihentikan, sebab referensi (landasan teori) yang mendukungnya sulit ditemukan, dan bahkan tidak ada dalam kamus teori pendidikan dan teori mendidik. Sebuah gagasan maupun strategi pembelajaran akan dianggap baik jika ada teori yang mendukung, seperti halnya dalam karya tulis ilmiah (http://www.indoforum.org/ showthread.php?t=65709).

Proses pendidikan dan pengajaran di sekolah harus mengembangkan konsep pendidikan humanis dan memberdayakan potensi anak. Fungsi institusi pendidikan menumbuhkan etika dan moral anak didik ketingkatyanglebihbaik dengancara atau proses yang baik pula. Dalam realitas di lingkungan pendidikan kita, masih adanya beberapa bentuk kekerasan merupakan indikator bahwa kegiatan pendidikan kita masih jauh dari nilai-nilai kemanusiaan dan di sinilah urgensi humanisasi pendidikan. Konsep humanisasi pendidikan merupakan upaya untuk menyiapkan generasi bangsa yang cerdas nalarpengetahuan, cerdas emosional dan cerdas spiritual, bukan malah menciptakan individu-individu yang berwawasan sempit, tradisional, pasif, tidak mampu menyelesaikan persoalan-persoalan yang dihadapi.

Perilaku kekerasan pada dasarnya adalah insting primitfmanusiauntukbertahanhidupdanmenunjukan kekuatan dan kekuasaan serta sebagai saluran ekspresi dan emosi yang terpendam. Pertanyaannya, kenapa insting primitf manusia dapat terjadi dalam dunia pendidikan di Indonesia, sehingga terjadi dekadensi kemanusiaan. Tim Evaluasi pendidikan pun dibentuk oleh Presiden yang diharapkan dapat meng-humanisasi kembali dunia pendidikan Indonesia. Seiring berjalannya tugas Tim tersebut, kekerasanpun masih sering terjadi di lingkungan pendidikan kita. Pada konteks ini, diperlukan kontrol dan pengawasan terhadap kegiatan di semua institusi pendidikan secara ketat (http://www.bloggaul.com/ foksraad/readblog/74581/kekerasan-dalam-duniapendidikan).

Ketiga, lingkungan masyarakat. Lingkungan 
masyarakat adalah tempat di mana anak belajar bersosialisasi, belajar bergaul, mengenal kebiasaan, mengenal aturan dan norma-norma yang berlaku di lingkungan masyarakat. Sudah barang tentu dalam proses belajar ini, anak cenderung meniru kebiasaan atau contoh-contoh yang diperoleh di lingkungan masyarakat. Mungkin saja bagi sebagian orang, kekerasan yang terjadi di masyarakat adalah hal yang wajar. Mereka beranggapan kekerasan adalah bagian dari dinamika kehidupan dalam bermasyarakat. Namun hal yang banyak dilupakan adalah semua norma, kebiasaan dan tradisi dalam masyarakat akan membentuk sikap dan tingkah laku anak.

Kekerasan yang sering terjadi di lingkungan masyarakat adalah bentuk kekerasan yang dapat berupa kekerasan verbal, seperti ejekan, hinaan, ancaman, rasisme; kekerasan secara mental atau psikologis, seperti mengucilkan, mempermalukan di depan umum, meneror lewat telepon genggam, membentak; dan kekerasan fisik, seperti memukul, menampar, menendang, meludahi, dan sebagainya. Memang pelaku biasanya sengaja menyakiti orang lain, baik secara fisik maupun psikologis, untuk mendapatkan kepuasan karena merasa lebih berkuasa sehingga target biasanya orang yang lebih lemah dan tidak cukup memiliki kekuatan dan dukungan sosial untuk melawan (Samhadi, 2009). Hal lain adalah perilaku para pemimpin masyarakat dan tokoh panutan sendiri yang tidak memberi contoh yang baik.

Peran media, terutama TV dan media cetak pun ikut menyebarkan kekerasan, berlomba-lomba mengekspose berbagai berita tentang kekerasan dengan bahasa yang provokatif. Dalam siaran TV kita dapat menyaksikan para tokoh saling berdebat dan saling mengancam untuk mempertahan pendapat dan prinsipnya. Seakan-akan menarik, tapi memalukan. Tayangan TV juga selalu menayangkan perkelahian antar pelajar, perkelahian antar mahasiswa, perkelahian antar desa, perkelahian antar sporter bola, pengerusakan rumah warga karena berbeda aliran, dan lain sebagainya. Beritaberita tersebut disampaikan sedemikian rupa dan ditayangkan secara berulang-ulang oleh stasiunstasiun TV, seakan-akan tidak ada ruang untuk berita lain. Perilaku kekerasan tampaknya menjadi tontonan yang menarik, komoditas tersendiri yang laku dijual di masyarakat. Namun, secara tidak disadari, tayangan-tayangan tentang berita kekerasan yang berulang-ulang tersebut dapat mempengaruhi pola pikir dan perilaku masyarakat untuk meniru perilaku tersebut. Sungguh ironisnya bangsa ini, medianya kurang selektif terhadap hal-hal yang tidak perlu diekspose secara besar-besaran dan berlebih-lebihan. Contoh lain adalah kasus video porno beberapa artis yang diblow-up sedemikain gencar. Tayangan berita semacam ini yang tidak ada rating dan batasan uisa dapat berpengaruh terhadap pola pikir anak-anak. Sungguh ironisnya bangsa ini, siaran dan tayangan TV-nya kurang atau dapat dikatakan tidak memiliki rasa perduli terhadap nilainilai pendidikan dalam siaran dan tayangan mereka. Pertanyaannya, seberapa efektit kah undang-undang penyiaran di negara ini? Mungkinkah pemerintah melakukan reformasi total terhadap undangundangan penyiaran? Ada ide di sebagian masyarakat bahwa yang diadili seharusnya bukan artis yang melakukan perbuatan tersebut, tetapi stasiun siaran TV dengan reporternya yang harus diadili, karena telah berlebih-lebihan menayangkan berita tersebut tanpa memandang faktor umur yang menyaksikan siaran dan nilai-nilai pendidikan dalam siaran dan tayangan tersebut.

Berdasarkan semua pemaparan di atas, menurut hemat penulis masyarakat harus melakukan pengawasan atau kontrol terhadap kegiatankegiatan siswa/mahasiswa di sekolah dan kampus, agar perilaku kekerasan dalam lingkungan sekolah dan kampus harus dapat dikurangi atau bahkan dihilangkan sama sekali. Para pelajar (siswa dan mahasiswa) pada awal memasuki sekolah dan kampus harus dikenalkan dengan konsep humanisme, demokrasi, karakter dan budaya bangsa, karena mereka adalah calon pemimpin bangsa ini. Tetapi bila pada awal masuk sekolah atau kampus mereka sudah dikenalkan dengan budaya kekerasan dan kemudian terbiasa dengan perilaku kekerasan tersebut, baik aktif maupun pasif, dapat dipastikan cara-cara tersebut pulalah yang akan ditempuh untuk menyelesaikan segala masalah ketika mereka sudah di masyarakat. Maka dari itu, diperlukan kontrol dan pengawasan secara terus menerus terhadap kegiatan ekstrakurikuler siswa dan mahasiswa. Konsep MOS, OSPEK, atau apapun namanya untuk kegiatan calon mahasiswa baru, perlu dilakukan perubahan paradigma mendasar agar lebih bermanfaat bagi para siswa atau mahasiswa baru. Untuk itu sekolah atau perguruan tinggi perlu mengembangkan konsep kegiatan MOS atau OSPEK yang penuh dengan nilai-nilai humanisme yang menjungjung tinggi 
perbedaan, keadilan dan rasa kemanusiaan. Karena dengan demikian siswa dan mahasiswa baru akan terdidik nilai-nilai positif sebagai dasar dari karakter dan kepribadian bangsa.

\section{E. Penutup}

Kata akhir dari tulisan ini, semua pihak yang berkepentingan dengan dunia pendidikan nasional untuk bersama-sama berupaya menghentikan bentuk kekerasan apapun, baik di lingkungan sekolah, lingkungan keluarga, dan lingkungan masyarakat. Orangtua, guru, dan para pemimpin harus menciptakan budaya santun, sopan, berbudi halus, toleran dan tepaseliro. Pendidikan kita harus mampu melahirkan manusia-manusia yang berbudaya, berbudi, bermoral dan berakhlak. Oleh karena itu, pendidikan budi pekerti yang mendidik kehalusan, sopan santun, menghargai yang lebih tua, menyayangi yang lebih muda dan menghormati hakhak asasi harus didesan dalam kurikulum pendidikan yang lebih bersifat aplikatif.

Kegiatan Masa Orientasi Siswa (MOS) dan Orientasi Pengenalan Kampus (OSPEK) perlu ditinjau kembali. Sekolah atau perguruan tinggi harus membuat aturan dan pengawasan yang ketat untuk mengendalikan kegiatan-kegiatan tersebut. Bila tidak, kegiatan tersebut harus dihentikan, karena tidak memiliki dampak positif dalam perkembangan pengetahuan, kepribadian, sikap, dan keterampilan siswa ataupun mahasiswa ketika mengikuti pendidikan di sekolah dan di kampus. Sekolah dan kampus harus berusaha menciptakan suasana pembelajaran yang menyenangkan, memanusiakan dan memberdayakan potensi anak. Pendidikan budi pekerti melalui keteladanan guru di sekolah ataupun pembinaan yang lebih intesif terhadap kegiatankegiatan siswa dalam wadah ekstrakurikuler kiranya dapat mencegah aksi-aksi kekerasan yang dilakukan kalangan pelajar.

\section{Daftar Pustaka}

Ancaman Kekerasan di Lembaga Pendidikan, November 26, 2007, http://anggara. org/2007/11/26/ancaman-kekerasan-dilembaga-pendidikan/, diakses pada selasa, $3 / 2 / 2009$.

Anwari WMK, Sebuah Refleksi http://www.jubileeschool.net/jubilee/index.php?option $=\mathrm{com}$ content\& $\quad$ task $=$ view\&id $=213 \&$ Itemid $=38$, diakses pada Selasa, 3/2/2009.

Assegaf, Abd. Rachman, dkk, Kondisi dan Pemicu Kekerasan dalam Pendidikan, Ringkasan Laporan Hasil Penelitian "Kondisi dan Pemicu Kekerasan dalam Pendidikan" http://www. ditpertais.net/istiqro/ist02-03.asp, diakses pada selasa, 3/2/3009.

Guru Gunakan Kekerasan, Ketinggalan Zaman, From:http://www. indoforum. org/showthread. php? $\mathrm{t}=65709$, diakses pada selasa, 3/2/2009.

H.A.R. Tilaar, Pendidikan, Kebudayaan, dan Masyarakat Madani Indonesia, (Bandung: Remaja Rosdakarya, 1999.

Hasil Seminar Nasional, Reaktualisasi Pendidikan Tanpa Kekarasa, Prodi Pendidikan Agama Islam, Fakultas Ilmu Agama Islam, Universitas Islam Indonesia Yogyakarta, 21 Februari 2009.

Kekerasan di Dunia Pendidikan, http://www. bloggaul.com/ foksraad/ readblog/ 74581/ kekerasan-dalam-dunia-pendidikan, diakses pada selasa, 3/2/2009.

Mulyadi, Seto, Suses dan Profesional Sebagai Guru, makalah disampaikan dalam seminar nasional tentang Reaktualisasi Pendidikan Tanpa Kekerasan, Program Studi Pendidikan Agama Islam Fakultas Ilmu Agama Universitas Islam Indonesia Yogyakarta, Sabtu, 21 Februari 2009.

Pendidikan tanpa KekerasanFrom:http://beutyreligi. wordpress. Com/2007/06/07/pendidikan-tanpakekerasan/, diakses pada selasa, 3/2/2009.

Pendidikan tanpa Kekerasan, From: http:// beutyreligi.wordpress.com/2007/ 06/07/ pendidikan-tanpa-kekerasan/, diakses pada selasa, 3/2/2009.

Samhadi, Sri Hartati, Budaya Kekerasan di Lembaga Pendidikan, From: http://www2.kompas. com/ kompas-cetak/0704/14/Fokus/3456065.htm, diakses pada selasa, 3/2/2009.

SuratKabar Kedaulatan Rakyat, Mengapa Kekerasan Ada di Mana-mana?, Opini, Tajuk Rencana Kedaulatan Rakyat, Kamis, 26 Februari 2009.

Tilaar, H.A.R. 1999. Pendidikan, Kebudayaan, dan Masyarakat Madani Indonesia. Bandung: Remaja Rosdakarya.

Undang-Undang Nomor 20 tahun 2003, tentang Sistem Pendidikan Nasional. 